\title{
Zastosowanie metody emisji akustycznej do lokalizacji uszkodzeń w zbiorniku na produkty ropopochodne
}

\author{
Application of acoustic emission method \\ for damages location in the in petroleum products tank
}

\section{Streszczenie}

W pracy przedstawiono zastosowanie metody emisji akustycznej do oceny stopnia uszkodzenia oraz lokalizacji miejsc o podwyższonym ryzyku dla bezpieczeństwa eksploatacji zbiorników niskociśnieniowych z podwójnym dnem stalowo-kompozytowym przeznaczonym na produkty ropopochodne. Sprawdzenia dokonano poprzez porównanie wyników miejsc wskazanych w badaniach metodą AT (acoustic testing) z odkrywkami dokonanymi podczas rewizji wewnętrznej. Budowa dna zbiornika oraz magazynowanie produktów uniemożliwiły przeprowadzenie inspekcji i ocenę stopnia uszkodzenia w trakcie eksploatacji. Dlatego też, zastosowanie metody AE daje możliwość dokładnej lokalizacji miejsc o podwyższonej intensywności sygnałów akustycznych bez potrzeby wyłączania obiektu z eksploatacji. Na podstawie pomiarów sygnałów AE można sporządzić wstępną ocenę stopnia uszkodzenia oraz kryteria AE. Badanie to pozwala na bezpieczną eksploatację bazy magazynowej jak również daje możliwość tworzenia harmonogramu oraz kosztorysu prac na poszczególnych zbiornikach.

Słowa kluczowe: zbiorniki niskociśnieniowe, emisja akustyczna, lokalizacja uszkodzeń

\section{Abstract}

The paper presents the application of acoustic emission method to assess the degree of damage and the location of places of higher risk the safe operation of low-pressure tanks with a double bottom steel-composite. The check is done by comparing the results of the places specified in the study by AT outcrops made during the internal audit. Construction bottom of the tank and the storage of the products made it impossible to inspect and assess the extent of damage during operation. Therefore, the method of AT makes it possible the exact location of increased intensity of the acoustic signals without having to switch the object of use. Based on measurements of signals AT can make a preliminary assessment of the extent of damage and the criteria AT. This study allows for the safe operation of storage facilities as well as the ability to create schedule and cost estimate work on individual tanks.

Keywords: low-pressure tanks, acoustic emission, acoustic testing, fault location

\begin{abstract}
Wstęp
Zbiorniki magazynowe na produkty ropopochodne ze względu na przechowywane medium stanowią poważne zagrożenie dla środowiska naturalnego, szczególnie w momencie niekontrolowanej awarii. Dlatego tak istotne staje się szukanie i opracowywanie skutecznych metod diagnostyki stanu technicznego zbiorników, szczególnie technik umożliwiających przewidywanie ewentualnego powstawania i rozwoju niebezpiecznych dla bezpieczeństwa zbiornika procesów destrukcyjnych. Obecnie tradycyjnym sposobem oceny stanu technicznego zbiornika magazynowanego jest wykonanie tzw. rewizji wewnętrznej polegającej na opróżnieniu zbiornika z magazynowanego produktu,
\end{abstract}

oczyszczenia dna poprzez piaskowanie i wyznaczenie na podstawie subiektywnej oceny obszarów, w których zostaną wykonane dodatkowe badania ultradźwiękowe grubości blach, a także jakości spoin. Już samo opróżnianie zbiornika powoduje duże zagrożenie dla środowiska naturalnego, ale największym zagrożeniem jest utylizacja zanieczyszczeń powstających z osadów oraz procesu piaskowania dna zbiornika. Badanie to, szczególnie gdy są to duże zbiorniki o pojemności powyżej $2000 \mathrm{~m}^{3}$, związane jest ze znaczną niepewnością wywołaną losowym wyborem miejsc do dalszych badań. Nawet wykonanie dodatkowego dna przy takich badaniach nie daje gwarancji niezawodności zbiornika, ze względu na duże prawdopodobieństwo ominięcia miejsc

Dr hab. inż. Grzegorz Świt, prof. nadzw. PŚw; mgr inż. Aleksandra Krampikowska - Politechnika Świętokrzyska, Wydział Budownictwa i Architektury; dr hab. inż. Krzysztof Schabowicz - Politechnika Wrocławska, Wydział Budownictwa Lądowego i Wodnego. 
niebezpiecznych. W konsekwencji może to prowadzić do powstawania różnych procesów destrukcyjnych. Szczególnie niebezpieczna jest korozja dna, gdyż brak dostępu do obu jego powierzchni utrudnia przeprowadzenie inspekcji i ocenę stopnia uszkodzenia w przypadku podwójnego dna. Prognozowanie trwałości dna zbiornika i jego podatności na różne uszkodzenia jest trudne ze względu na wielorakość czynników mających wpływ na procesy destrukcyjne. Dlatego tak istotne jest poszukiwanie metod diagnostyki blach zbiornika w warunkach eksploatacji umożliwiających lokalizację miejsc niebezpiecznych, intensywność ewentualnych procesów destrukcyjnych, ale także rozpoznawanie ich.

Techniką, która spełnia zdaniem autorów, wszystkie te warunki jest metoda emisji akustycznej. Polega ona na rejestracji i analizie fal sprężystych generowanych przez różne procesy destrukcyjne. Są to głównie sygnały generowane przez reakcje chemiczne, rozwój procesów korozyjnych, pękanie produktów korozji, przesiąkanie magazynowanego produktu, praca pocienionych blach i spoin, czy też powstawanie i rozwój pęknięć. Emisja akustyczna towarzyszy jedynie procesom aktywnym, rozwijającym się [1]. Nie występuje natomiast w przypadku uszkodzenia korozyjnego stabilnego, to znaczy, gdy nie powiększa się ono, a produkty korozji nie zmieniają swojej struktury.

W pracy przedstawiono wyniki badań, których celem było wykrycie miejsc o podwyższonej aktywności akustycznej blach stalowych i płaszcza kompozytowego dna zbiornika ze względu na zmianę przechowywanego medium z ciężkiego oleju opałowego (mazut) a olej lekki, co wiąże się z innym składem chemicznym. Ma to istotne znaczenie na prędkość rozwoju potencjalnych procesów korozyjnych.

\section{Przeprowadzone badania}

Badaniom poddano zbiornik cylindryczny o osi pionowej, $z$ dachem stałym. Pojemność nominalna zbiornika wynosiła $V=10000 \mathrm{~m}^{3}$, a jego główne wymiary były następujące:

- średnica wewnętrzna płaszcza - dw = $31520 \mathrm{~mm}$

- średnica zewnętrzna płaszcza $\quad-d z=32370 \mathrm{~mm}$

- wysokość płaszcza - hp $=13650 \mathrm{~mm}$

Płaszcz zbiornika pokryty był izolacją termiczną z wełny szklanej grubości 120 mm, osłoniętą od zewnątrz cienkimi ocynkowanymi blachami. Płaszcz składał się z dziewięciu pierścieni z blach (tzw. carg) o projektowanych grubościach licząc od dołu: 16, 14, 13, 12, 10, 9, 8, 6 mm (rys. 1).

a)

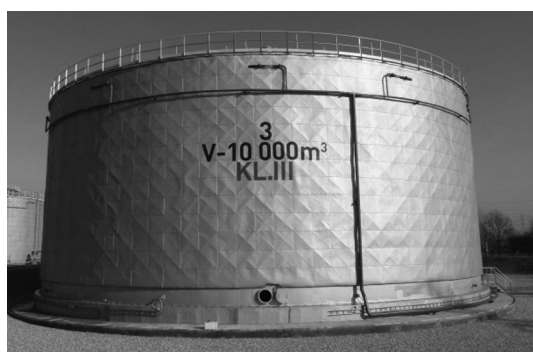

b)

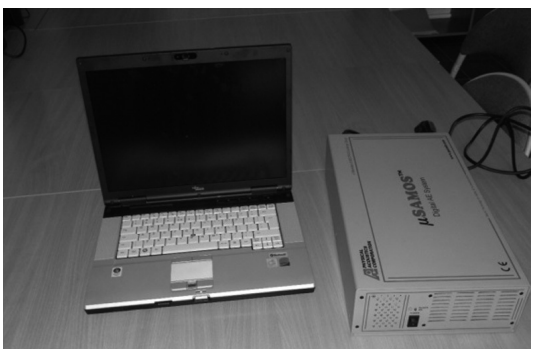

Dno zbiornika było płaskie, a według projektu miało grubość $10 \mathrm{~mm}$ w pierścieniu obwodowym (przy połączeniu z cargą dolną) i 7 mm w części środkowej. Wewnątrz zbiornika wykonano płaszcz wewnętrzny kompozytowy z tkaniny szklanej oraz żywicy poliestrowej wraz z systemem ostrzegania o przeciekach „Tanksystem”. Zbiornik posadowiony na fundamencie betonowym wysokości $h=1000 \mathrm{~mm}$. Pomiędzy dnem zbiornika, a fundamentem wykonano podsypkę piaskowo-mazutową.

Na płaszczu zbiornika umieszczono w ośmiu miejscach czujniki emisji akustycznej na wysokości $700 \mathrm{~mm}$ od dna zbiornika, umożliwiające lokalizację obszarów aktywnych emisyjnie. Rozmieszczenie czujników pokazano na rysunku 1b. Czujniki oznaczono odpowiednio cyframi od 1 do 8 i rozmieszczono w równych odległościach po obwodzie zbiornika.

Do badania zastosowano rezonansowe czujniki emisji akustycznej częstotliwości o zakresie $55 \mathrm{kHz}$ oraz 24 kanałowy procesor emisji akustycznej $\mu$ Samos [6] zaprezentowany na rysunku $1 \mathrm{c}$.

Przed przystąpieniem do właściwego pomiaru przeprowadzono kalibrację czujników polegającą na zarejestrowaniu wzorcowego sygnału, wygenerowanego w określonej odległości od czujnika emisji akustycznej. Jako sygnał wzorcowy zastosowano wzorzec HSU-NILSENA [2:6], sygnał akustyczny towarzyszący złamaniu grafitu ołówka na powierzchni badanego obiektu. W ten sposób sprawdzono poprawność pracy systemu pomiarowego.

\section{Rezultaty badań}

W ocenie stopnia uszkodzenia zastosowano zmodyfikowane kryteria podane w [2]. Oparto je na analizie sumy sygnałów emisji akustycznej zarejestrowanych podczas godzinnego monitoringu oraz wybranych parametrów emisji akustycznej: amplituda, energia, czas trwania. Zgodnie z przyjętymi kryteriami w zależności od zarejestrowanej liczby zdarzeń akustycznych zbiornik zaliczany jest do jednej z pięciu kategorii uszkodzenia: A - E. Przypisanie odpowiedniej kategorii zbiornikowi pozwala na wstępną ocenę stopnia skorodowania. Zgodnie z opracowaną klasyfikacją zbiorników i doświadczeniem zdobytym na podstawie przeprowadzonych badań przyjęto cztery stopnie skorodowania zbiornika (tabl. I). Przyjęte kryteria pozwalają na przybliżoną ocenę stanu technicznego dna zbiornika jak i na określenie harmonogramu kolejnych przeglądów względnie napraw [2].

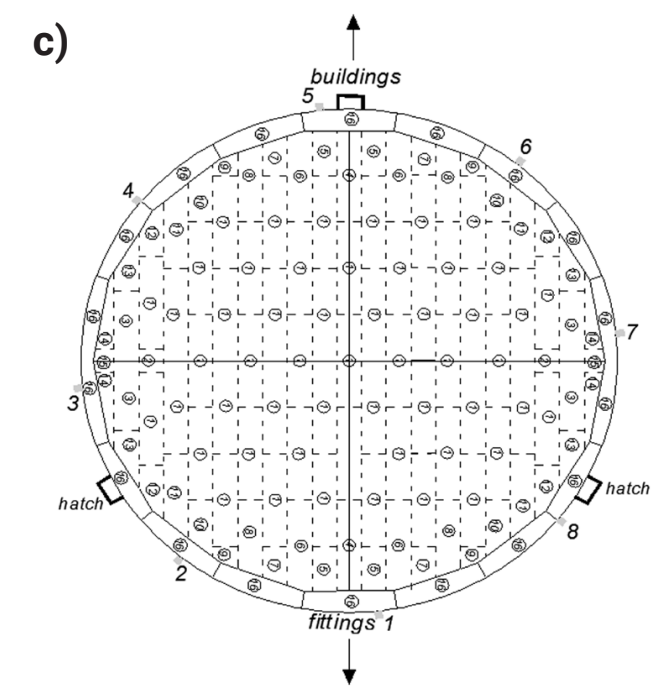

Rys. 1. Badany zbiornik: a) widok ogólny, b) rozmieszczenie czujników w trakcie lokalizacji miejsc o podwyższonej aktywności emisji akustycznej na dnie zbiornika, c) zestaw pomiarowy AT: 24- kanałowy procesor $\mu$ SAMOS oraz czujnik rezonansowy o częstotliwości 55 kHz [3-5] Fig. 1. The test tank: a) general view, b) a sensor arrangement during the localizing sites of enhanced activity acoustic emission bottom of the tank, c) the measurement set emission acoustic: 24- channel processor $\mu$ SAMOS sensor and a resonant frequency of 55 kHz [3-5] 
Tablica I. Kryteria wstępnej klasyfikacji zbiorników w zależności od wybranych parametrów AT

Table I. The criteria for initial screening of tanks depending on the selected parameters AT

\begin{tabular}{|c|c|c|c|c|}
\hline Klasa zbiornika & $\begin{array}{l}\text { Średnia liczba } \\
\text { zdarzeń AE wg [1] }\end{array}$ & $\begin{array}{l}\text { Amplituda } \\
\text { [dB] }\end{array}$ & $\begin{array}{l}\text { Energia AE } \\
{[\mu s v / \text { count }]}\end{array}$ & $\begin{array}{l}\text { Czas trwania } \\
\text { sygnału AE }[\mu \mathrm{s}]\end{array}$ \\
\hline $\begin{array}{l}\text { A - brak ognisk korozyjnych lub niewielkie ogniska } \\
\text { korozyjne, następne badanie po } 10 \text { latach }\end{array}$ & $<400$ & $40-60$ & $<10$ & $<5000$ \\
\hline $\begin{array}{l}\text { B - brak ognisk korozyjnych lub niewielkie ogniska } \\
\text { korozyjne, następne badanie po } 5 \text { latach }\end{array}$ & $<1500$ & $40-60$ & $<50$ & $<50000$ \\
\hline $\begin{array}{l}\text { C - niewielkie ogniska korozyjne na znacznej po- } \\
\text { wierzchni dna. Ewentualnie wymiana częściowa dna } \\
\text { jeżeli taka możliwość istnieje. Następne badanie } \\
\text { po } 3 \text { latach }\end{array}$ & $<3000$ & $40-80$ & $<200$ & $<100000$ \\
\hline $\begin{array}{l}\text { D - Znaczna korozja dna zbiornika. Ewentualna wy- } \\
\text { miana częściowa lub całkowita blach dna. Remont } \\
\text { należy przeprowadzić w ciągu } 1 \text { roku. W przypadku } \\
\text { remontu częściowego przeprowadzić lokalizację } \\
\text { pełną uszkodzeń metodą emisji akustycznej }\end{array}$ & $<5000$ & $40-70$ & $<500$ & $<150000$ \\
\hline $\begin{array}{l}\text { E - dno skorodowane z wyraźnymi zmianami struk- } \\
\text { tury blach dna zbiornika. Zbiornik przeznaczony } \\
\text { do natychmiastowego remontu i całkowitej wymia- } \\
\text { ny dna }\end{array}$ & $>5000$ & $40-50$ & $>500$ & $>150000$ \\
\hline
\end{tabular}

W trakcie pomiaru rejestrowano podstawowe parametry sygnałów emisji akustycznej. Analizę oparto o sumę zdarzeń (events). Pozostałe parametry: czas trwania sygnału (duration), amplituda sygnału oraz energia sygnału w ocenie spełniają rolę pomocniczą.

Jak pokazano na wykresach sumlacyjnych przedstawionych na rysunku 2 w okresie 60 minut czujnik nr 1 zarejestrował 421 zdarzeń. Czujnik nr 4 w tym samym czasie zarejestrował 2 579. Średnia wartość liczby zdarzeń przez czujniki wynosiła 1500 sygnałów. Zgodnie z kryterium podanym przez pracy [2] zbiornik można przyporządkować do klasy B.
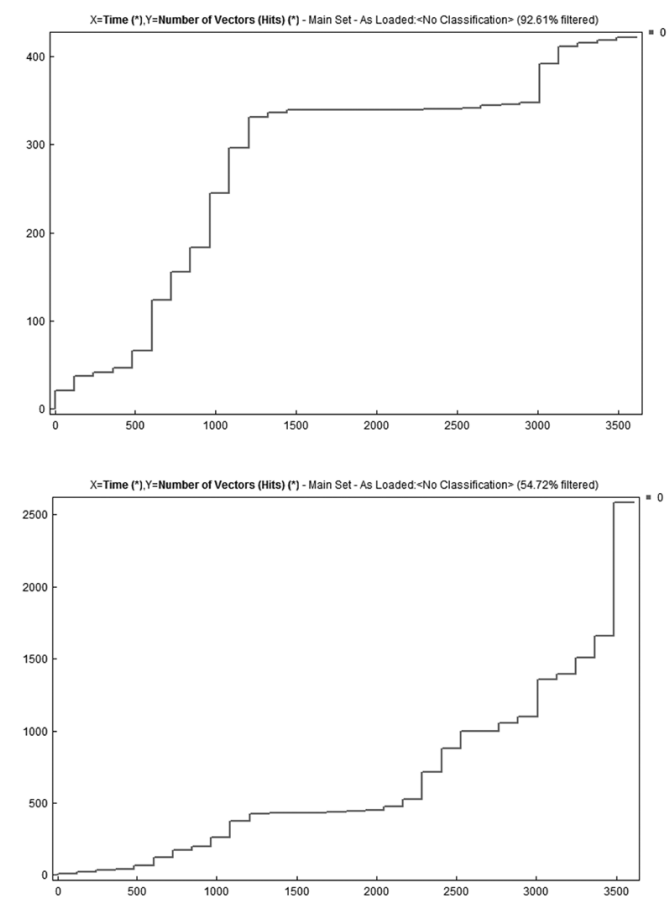

Rys. 2. Suma zdarzeń w funkcji czasu zarejestrowana przez czujnik w punkcie 1 i 4

Fig. 2. The sum of the events as a function of time recorded by the sensor in step 1 and 4
Dla pełniejszej oceny stanu dna zbiornika analizowano także trzy pozostałe parametry, których wybrane parametry pokazano na rysunku 3.
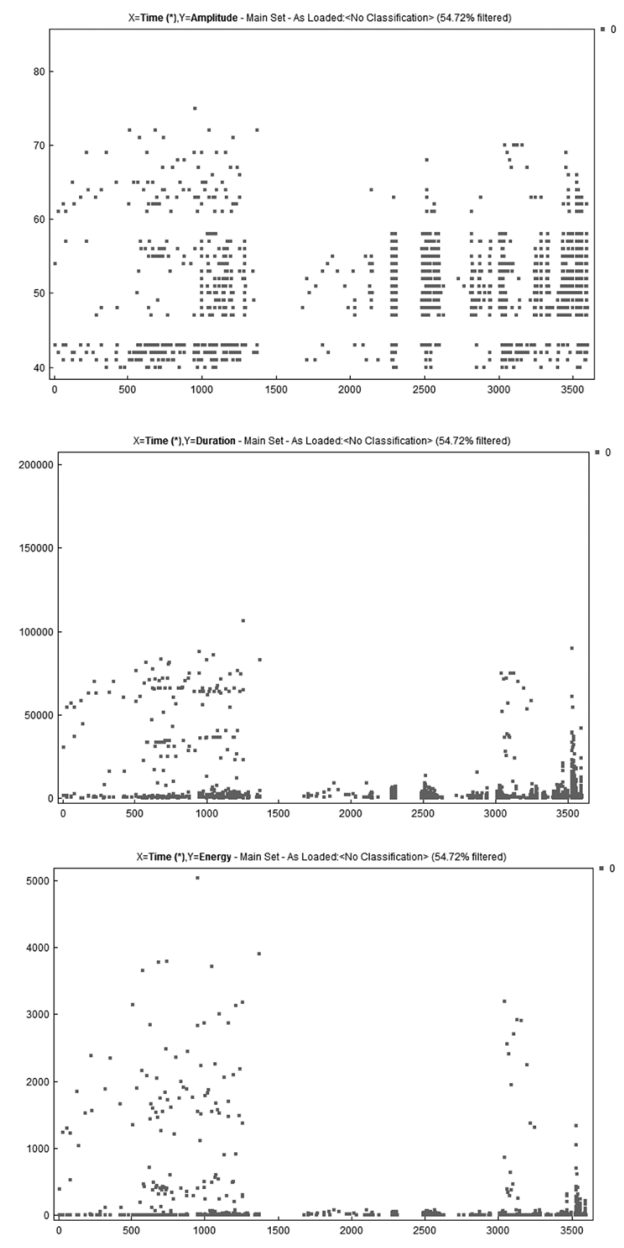

Rys. 3. Punktowy wykres amplitudy, czasu trwania oraz energii sygnału emisji akustycznej w funkcji czasu zarejestrowany przez czujnik w punkcie 4

Fig. 3. Scatter plot of amplitude, duration and energy acoustic emission signal as a function of time recorded by the sensor in step 4 
Zarejestrowane wartości parametrów w obrębie czujnika 4 sugerują iż w zbiorniku obecnie nie przebiegają procesy destrukcyjne związane ze zjawiskiem korozji dna zbiornika.

W prezentowanym przypadku zarejestrowano sygnały o amplitudzie do $80 \mathrm{~dB}$ o małej energii i długim czasem trwania. Sygnały o amplitudzie powyżej $65 \mathrm{~dB}$ i długim czasie trwania sugerują odkształcenia się blach w obrębie połączenia dolnej cargi oraz dna zbiornika.

Dla pełnej analizy wykonano lokalizację miejsc, w których występuje pocienienie grubości blach dna i ich falowanie pod wpływem oddziaływania medium w zbiorniku oraz karby wynikające z błędów w wykonaniu spoin. Lokalizację miejsc o wzmożonej aktywności emisji akustycznej zaprezentowano na rysunku 4.

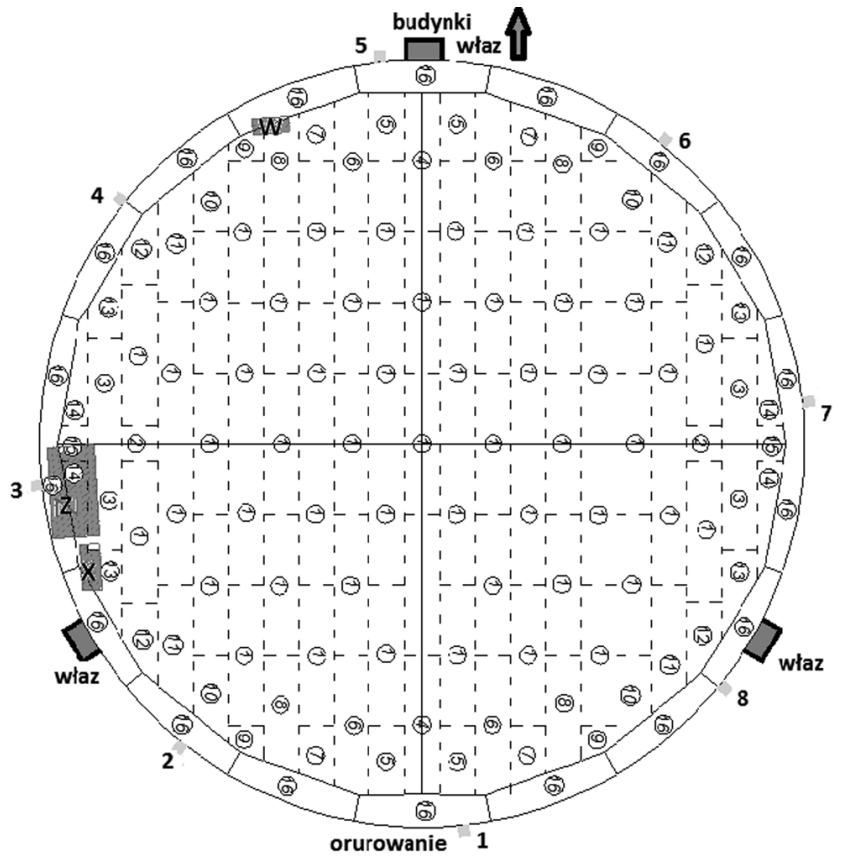

Rys. 4. Lokalizacja miejsc o podwyższonej aktywności emisji akustycznej sugerująca obszary o zmniejszonej grubości blach dna lub nieciągłości spoin

Fig. 4. Location of sites with enhanced acoustic emission activity suggesting areas of reduced thickness of the bottom plate or weld discontinuities
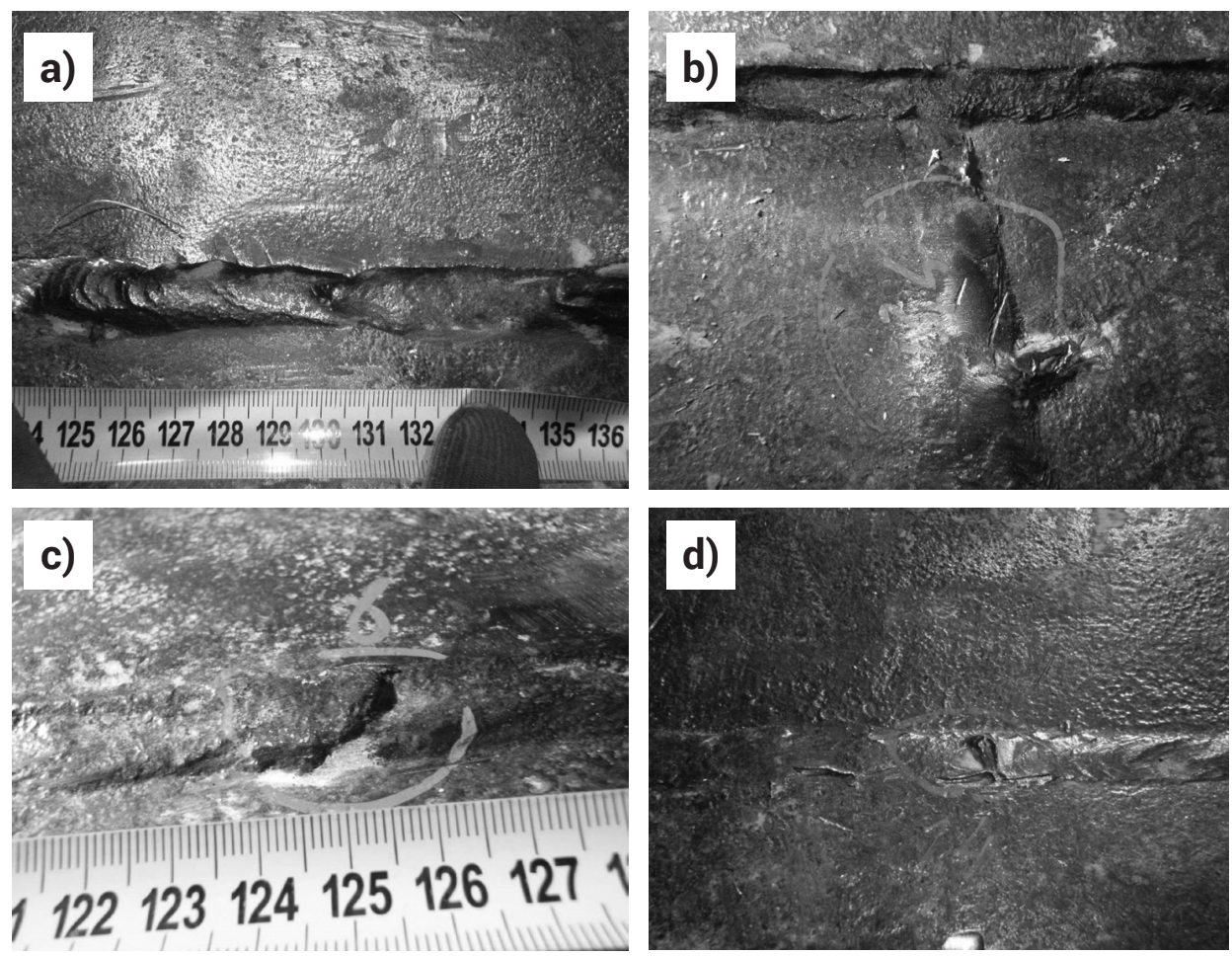

Rys. 6. Stwierdzone niezgodności: a) widoczne na spoinie wklęśnięcie lica - „przekoszenie” blach; b) w spoinie nr 3 - niewłaściwy kształt spoiny; „przekoszenie"; c) i d) niewłaściwe rozpoczęcie spoiny, brak wypełnienia lica i uszkodzenia mechaniczne spoiny Fig. 6. The latter shall: a) visible on the weld face Dent - "skewing" sheet; b) in the joint No. 3 - improper weld shape, "skewing"; c) and d) inadequate start weld not filled faces and mechanical joints 


\title{
Podsumowanie
}

Przedstawiona metoda pomiaru emisji akustycznej okazała się bardzo skuteczną techniką oceny stanu technicznego dna zbiornika magazynowego na produkty ropopochodne. Metoda ta umożliwia lokalizację potencjalnych uszkodzeń bez potrzeby wyłączania zbiornika z eksploatacji, a także bez opróżniania go z produktu, co zabezpiecza środowisko naturalne przed ewentualnym skażeniem. Szybkość badań oraz jak pokazują wyniki sprawdzające (rewizja wewnętrzna) pozwalają na stwierdzenie, że metoda ta jest jedną z efektywniejszych, nisko kosztowych i bezpiecznych dla środowiska. Najważniejszą jej zaletą jest możliwość oceny stopnia uszkodzenia w przypadku obszarów trudno dostępnych bez potrzeby wyłączania i opróżniania z produktów niebezpiecznych. Na podstawie przeprowadzonych badań stwierdzono, że:

- klasa zbiornika B - średnia liczba sygnałów akustycznych $<1500$,

- niewielkie ogniska korozyjne i nieszczelne zawory,

- zalecana szczególna uwaga przy zmianie magazynowanego medium (możliwy wzrost procesów korozyjnych),

- niedoskonałości przy wykonywaniu spoin,

- lokalizacja pęknięcia spoiny,

- zbiornik zakwalifikowany do następnego przeglądu metodą emisji akustycznej za 6 lat.

\section{Literatura}

[1] P. J. Van De Loo, D. A. Kronemeijer. Screening of tank bottom corrosion with a single point AE detector. AE- simple, Journal of Acoustic Emission, No 18 (2000), s. 174-180.

[2] Świt G., Trąmpczyński W.: Preliminary classification method of damage, of the tanks for petroleum products bottoms caused by corrosion, with use of acoustic emission, Proceedings of conference scientific-technical "Steel Structures", Kielce - Suchedniów, 2-4 July 2014, s. 155-158, Poland.

[3] Goszczyńska B., Świt G., Trąmpczyński W.: Monitoring of active destructive processes as a diagnostic tool for the structure technical state evaluation, Bulletin of the Polish Academy of Sciences: Technical Sciences, 61 (1), s. 97-109, 2013.

[4] Goszczyńska B., Świt G., Trąmpczyński W.: Assessment of the technical state of large size steel structures under cyclic load with the acoustic emission method IADP, Journal of Theoretical and Applied Mechanics 52 (2), s. 289-299.

[5] Goszczyńska B., Świt G., Trąmpczyński W., Krampikowska A.: Application of the acoustic emission (AE) method to bridge testing and diagnostics comparison of procedures, IEEE Xplore - IEEE Proceedings, s. 1-10, 2012, Bejiging, China.

[6] Świt G.: Diagnostics of prestressed concrete structures by means of acoustic emission - ICRMS Reliability, Maintainability and Safety, 2009. IEEE Xplore - IEEE Proceedings, s. 958-962, 2009, Chengdu, China.

\section{MIEZDZYNARODOWA KONFERENCJA LUTOWNICZA}

\author{
Zarząd Glówny SIMP \\ Dolnośląska Sekcja Spawalnicza SIMP
}

Katedra Materlałoznawstwa, Wytrzymałości i Spawalnictwa Politechniki Wrocławskiej

Wydział Mechaniczny Politechniki Wrocławskiej

zapraszają do udziału

w 5. Międzynarodowej Konferencji Naukowo - Technicznej pod hasłem „POSTEP W TECHNOLOGIACH LUTOWANIA"

WROCLAW 26-28 wrzesnia 2016 (poniedziałek - środa)

pod przewodnictwem naukowym

Prof. dr hab. inż. dr h.c. (mult.) Wadysława Wlosińskiego, PAN Warszawa

\section{KOMITET ORGANIZACYJNY}

Prof. dr hab. inż. Zbigniew/Mirski - Przewodniczacy Komitetu Organizacyjnego

tel.71/3202142,e-mail: zbigniew.mirski@pwr.edu.pl

Dr inż. Tomasz Piwowarczyk - Sekretarz Komitetu Organizacyjnego

tel.692448319, e-mail: tomasz.piwowarczyk@pwr.edu.pl

Zainteresowanych Panstwa prosimy o kontakt z sekretariatem Konferencji:

Mgr inż. EWa Harapinska

tel. 784927814, e-mail: ewa.harapinska@pwr.edu.pl

www. konferencjalutownicza.pwr.wroc.pl 